\title{
A Review of the Impact of Traditional Culture on Auditing
}

\author{
Tengfei Wu \\ Jinan University, Guangzhou, China \\ Email:wtf19950108@163.com
}

How to cite this paper: Wu, T.F. (2019) A Review of the Impact of Traditional Culture on Auditing. American Journal of Industrial and Business Management, 9, 780-788.

https://doi.org/10.4236/ajibm.2019.93051

Received: March 5, 2019

Accepted: March 24, 2019

Published: March 27, 2019

Copyright (c) 2019 by author(s) and Scientific Research Publishing Inc. This work is licensed under the Creative Commons Attribution International License (CC BY 4.0).

http://creativecommons.org/licenses/by/4.0/

\section{cc) (i) Open Access}

\begin{abstract}
This paper reviews the main literature on cultural research and auditing research at home and abroad, and provides a theoretical basis for the study of the impact of traditional culture on auditing. The following chapters of this paper are divided into the following sections: the first section introduces the research literature on auditing, the second section introduces the literature on cultural development level, the third section introduces the impact of culture on business and individual behavior, the fourth section introduces the literature on the impact of culture on accounting and auditing, Section 5 is the research literature on the impact of Chinese traditional culture on corporate behavior, and Section 6 is a summary and review of domestic and foreign literature.
\end{abstract}

\section{Keywords}

Traditional Culture, Auditing, Accounting, Corporate Behavior

\section{Review of the Audit Research Literature}

Audit fees and audit quality have always been the focus of attention in the field of accounting research at home and abroad. Specifically, the existing research mostly examines the impact on audit fees and audit quality from the corporate and individual levels. From the perspective of enterprise level, Zhang Rui took the A-share listed companies in China from 2007 to 2014 as the research object, and investigated whether there were initial cost discounts for different types of change and the impact of this phenomenon on audit quality when the accounting firm of the audited listed company changed. Fang Hongxing found that the size of the company, the complexity of the business, the nature of state-owned property rights, the reputation of the accounting firm and the degree of assurance of the internal control services it provides are significantly positively corre- 
lated with the internal control audit fees; the quality of the company's internal control, continuous internal, the control audit period and the firm's integrated audit are significantly negatively correlated with the internal control audit fees. Yan Yanli and Lu Guihua researched from the perspective of corporate tax credit, the research results show that the audit fees of tax-honored enterprises are significantly lower than non-taxable credit companies. Wang Bing used the provision of travel expenses to auditors as a research perspective to reflect the economic binding relationship between listed companies and accounting firms and the signal of social relations. The empirical results found that, except in individual models, the company provided that the travel expenses under the weak conditions impaired the quality of the audit. There is no consistent evidence that there is a significant relationship between the travel expenses and the reduction in audit quality. From a personal perspective, Simunic believes that the audit cost of a company depends on the auditor's efforts and the expected litigation risk. Religious culture can influence the auditor's efforts through the audit planning process [1]. According to DeAngelo, the quality of auditing depends on the combined role of auditor's professional skills and audit independence. Professionally skilled auditors can use their accumulated audit knowledge and experience to identify errors and fraud in customer financial reports.

Recent studies have suggested that institutional factors as external factors affecting audit organization behavior will affect regional audit market structure and thus affect accounting information quality [2]. Liu Wenjun took the listed company in 2008-2011 as a research sample. The study found that the closer the auditor is to the customer, the lower the absolute value of the company's manipulative accruals, and the lower the probability of being issued a standard unqualified opinion. Liu Yingfei and Ding Wei used the 2009-2014 China A-share listed company as a research sample. The study found that companies with higher social capital stocks at the headquarters had lower audit fees. Further research by Yan Yanli and Lu Guihua shows that the audit fees of tax-integrity companies are significantly lower than those of non-tax credit companies, both in the eastern regions with higher legal standards and in the central and western regions with lower legal standards. These studies study the impact on auditing from a macro perspective, both from the formal system and from the informal system level. This paper studies the impact on audit fees and audit quality from the perspective of traditional culture.

\section{The Impact of Culture on the Level of Economic Development}

For the determinants of economic development, economists' attention has undergone an evolving process. Early literature studies the accumulation of production factors and technological progress, and later focuses on policies and incentives that affect factor accumulation and technological progress, and updated research explores policies. And the institutional factors behind the incentives, in decades of research, economists step by step to deep-seated influence factors. 
Economists are beginning to explore deeper causes than institutions, including geography, history, and culture, the so-called "fundamental factors". Only by identifying the long-term effects of fundamental factors can institutional reform and policy intervention be known. The boundaries of effects improve our ability to assess policy shocks.

In this new field of study, the role of culture is given special attention. The historical and geographical factors of the era are often influenced by the cultural characteristics passed down from generation to generation to influence the modern economy. Therefore cultural factors are at the core of such literature. About Spolare and Wacziarg, for the first time, examined the relationship between gene distance (the degree of genetic difference between two populations) and the level of economic development. They argue that genetic distances represent differences in cultural characteristics such as beliefs, practices, habits, prejudices, and customs (they use the term "group characteristics") because the greater the genetic distance of different groups, the more they mean on the lineage. The longer the separation, the greater the cultural difference, and ultimately the difference in the level of economic development. The channel of influence is the hindrance effect of cultural differences on technology diffusion. Other literature focuses on topics other than economic growth. Guiso et al. studied the cultural barriers represented by genetic distances for trade and investment, and Desmet et al. used the European World Value Survey Data (WVS) to confirm genes [3]. Distance can indeed reflect cultural differences, and cultural differences can affect national unity.

An important channel for culture to influence economic exchanges is the impact on the level of trust between people. Mutual trust is an important social capital that plays an important role in economic development [4]. Guiso et al. used the World Values Survey (WVS) to measure the level of mutual trust between EU countries [3]. The study found that a common cultural foundation can effectively deepen the level of mutual trust between the people of two countries. Increased levels can promote mutual trade and investment. On this basis, we can think that people with the same culture and similar levels have higher levels of trust, and the transaction costs of trade and cooperation are lower, which is conducive to economic exchanges and development.

\section{The Impact of Culture on Business and Individual Behavior}

The literature has discussed the impact of culture on corporate finance, such as investment decisions and risk taking. Hilary and Hui extended the research the relationship between religious culture and risk aversion from the individual level to the organizational level, and empirically tested the impact of religious tradition on corporate risk-taking and investment decisions [5]. The study found that the stronger the religious position of the listed company, the more obvious the risk aversion behavior of the company, the smaller the standard deviation of the 
stock market return rate and the total return on assets, and the lower the company-specific risk and systemic risk.

Li Cunchao and Wang Xingyuan pointed out that business ethics has a normative and restrictive role in corporate behavior in terms of money, contract, honesty and social responsibility, and provides a normative framework and behavior for corporate business ethics. The norms, while the values and social trust formed by traditional culture are closely related to the regulation of corporate ethical behavior. Religious culture is an important part of traditional culture and plays a very important role in the informal system of a society. Brammer et al. examined the impact of religious beliefs on corporate social responsibility and the differences between different denominations and different social responsibilities. The study found that individuals with religious beliefs have a clear attitude towards corporate social responsibility compared to non-religious individuals. This kind of support preference differs among different religious factions, and different sectarians recognize the preference of corporate social responsibility content. For example, traditional Chinese culture pays more attention to collectivism and pays more attention to the interests of the collective. Corporate social responsibility is more about the obedience of the collective. The culture of European and American countries pays more attention to individualism and links corporate social responsibility with personal interests. Griffin and Sun studied the relationship between the religious beliefs of stakeholders and the disclosure of voluntary social responsibility information, and found that the intensity of religious beliefs is negatively related to the disclosure of social responsibility information, while the number of sectarian ownership and social responsibility information disclosure is positive related [6]. When further dividing social responsibility into environmental information and other social responsibility information, it is found that the intensity of religious belief and the number of sectarian ownership are significantly positively correlated with environmental information disclosure. The above conclusions show that religious belief can promote the disclosure of corporate social responsibility information, especially environmental information disclosure, which is mainly manifested in the organizational effect of religious influence. At the same time, the market level can also price religious influences. During the disclosure of social responsibility information, investors have obtained a significantly positive market return.

The current theory holds that culture affects people's cognition, communication and interaction [7], which is a deep force affecting economic growth. Communication and collisions between multiple cultures may influence the formation of innovative ideas. Creativity is based on the diversity of skills, ideas, and cultures that lead to a relaxed culture that is more receptive to unconventional ideas that break through the norm, and that creates a highly competitive social environment that is diverse in culturally diverse regions. People in the background communicate more frequently, which facilitates the spillover of local knowledge and promotes innovation [8]. Page pointed out that diversified 
ideas and understanding can improve problem solving and predictive ability.

The literature has discussed the impact of culture on corporate finance, such as investment decisions and risk-taking. A growing stream of research uses religion as a proxy for culture and social norms and suggests that religion is a key social mechanism for influencing beliefs and behaviors. In fact, consistent with the notion that a religion-based social identity and sense of belonging affects behavior of individuals and firms, recent literature gives evidence that local religious beliefs impact a wide range of corporate decisions, including financial reporting irregularities and accruals-based earnings manipulation [9]. Hilary and Hui extended the research on the relationship between religious culture and risk aversion from the individual level to the organizational level, and empirically tested the impact of religious tradition on corporate risk-taking and investment decisions. The study found that the stronger the religious position of the listed company, the more obvious the risk aversion behavior of the company, the smaller the standard deviation of the stock market return rate and the total return on assets, and the lower the company-specific risk and systemic risk.

\section{The Impact of Culture on Accounting and Auditing}

As a collective psychological model that distinguishes members of different nationalities, culture has an important influence on accounting standards and accounting practices in various countries. At present, domestic and foreign scholars have used theoretical analysis and empirical test methods to study the impact of culture on accounting conservatism, financial disclosure and accounting standards coordination.

\subsection{The Influence of Culture on Accounting Conservatism}

In the influence of research culture on accounting conservatism, Schultz \&Lopez used France, Germany, and the United States as examples to study the degree of accounting conservatism in terms of product quality assurance costs, and studied accounting personnel in different countries under similar financial reporting standards [10]. Whether the degree of application of robustness is different in the face of the same economic facts, and the conclusion that there is a significant positive correlation between the uncertainty avoidance cultural dimension and the robustness.

\subsection{The Impact of Culture on Financial Information Disclosure}

In the impact of research culture on financial disclosure, Tsakumis or some matters were disclosed as research objects, and it was pointed out that accounting personnel in the United States (as a representative of lower conservatism and confidentiality) were more inclined to disclose contingent events than Greek accountants, thus indirectly verifying cultural disclosure of financial disclosure in intrinsic influence [10]. 


\subsection{The Impact of Culture on the Coordination of Accounting Standards}

In the influence of research culture on the coordination of accounting standards, Clements, Neill and Stovall found that a country's accounting organizations are internationally aware of the acceptance of the International Accounting Standards by 104 members of the International Accounting Association [11]. The degree of acceptance and adoption of the standards issued by the Accounting Federation is influenced by the culture of the country. Specifically, whether a country's accounting organization adopts the rules of the International Accounting Federation's promulgation of guidelines has a significant negative correlation with the country's level of individualism and the degree of uncertainty avoidance.

\subsection{The Impact of Culture on the Auditing}

In addition to accounting disclosure, audit quality is also an important indicator of the information environment. Audit opinions can effectively reveal information risks and agency problems caused by information asymmetry. From the perspective of the competitive theory hypothesis of risk aversion and social identity, Omer et al. examined the impact of religion on the decision-making judgment of auditors' audit opinion on continuing operations, and found that when the accounting firm is located in a more religious area, it is possible to issue non-standard audit opinions to clients in order to deal with the risk of legal litigation of uncertainty, rather than the acquiescence of customer preferences due to social identity. Taking China's capital market as the background, Chen Donghua et al. examined the impact of China's religious tradition on the accounting information environment from the perspective of corporate irregularities, earnings management, and audit opinion types. The study found that the stronger the religious tradition of the listed company, the lower the probability of accounting irregularities, the smaller the degree of earnings management of listed companies, and the lesser non-standard audit opinions issued by external auditors. The relationship is more obvious in areas with a better legal system environment. Some scholars further examined the relationship between religious environment and corporate governance from the perspective of financial reporting information. Dyreng et al. found that the higher the level of religious belief in the headquarters, the lower the probability that the profit will meet or exceed the analyst's forecast. At the same time, the higher the accrual quality of such companies, the more likely the financial fraud may be [12]. Low, the possibility of restatement of financial statements is also lower. Based on the 610,000 questionnaires, McGuire et al. examined the impact of religion on respondents from three levels of cognition, impact, and behavior. It was found that religious influences and financial reporting violations were significantly negative relationships; companies with weak external supervision have stronger influences on religion; in addition, religious influences are negatively correlated with excess 
accruals, but are positively related to real-life earnings management, and religions affect the choice of management earnings management tools.

Wang Bing et al. used the provision of travel expenses to auditors as a research perspective to reflect the economic binding relationship between listed companies and accounting firms and the signal of social relations. The empirical results found that, except in individual models. The company provided that the travel expenses under the weak conditions impaired the quality of the audit. There is no consistent evidence that there is a significant relationship between the travel expenses and the reduction in audit quality. Du Xingqiang conducted a study on Chinese listed companies from 2001 to 2010. The results showed that some listed companies established a binding relationship with the auditors by providing courtesy to the auditors, thus eroding the substantive audit independence. Chen Shenglan et al. examined how anti-corruption in China affects audit pricing. The results show that audit fees paid by companies with political connections after 2012 increased by $38 \%$ compared to companies without political connections. Anti-corruption raises audit risk related to financial reporting quality and operational uncertainty as an important channel for its impact on audit pricing. Jha believes that social capital measures the level of mutual trust in a region. Auditors judge the credibility of their customers based on the location of the company's headquarters, and charge more audit fees when they have less trust in customers. According to the review of relevant literature, this paper initially believes that the human culture in traditional culture has a negative impact on audit fees and audit quality.

\section{The Influence of Chinese Traditional Culture on Corporate Behavior}

The harmonious concept formed in our traditional culture contains three aspects: harmony between man and nature, harmony between people and harmony between man and himself. This contains the ethical thoughts of "Heaven and Man", "Tao Law Nature", the concept of "the noble monk" and the values of "seeing fortune and forgetting". This not only makes people pay attention to self-cultivation, pursues the harmony between man and nature, but also guides people to pay attention to the interests of others. The results of Gu Zhihui show that Confucianism reduces its supervision expenditure by instilling in the agent the concept of "sadness" and "self-discipline". Confucianism requires agents to abide by the professional ethics of "faithfulness" and the "righteousness" concept, and ultimately achieve the goal of reducing the agent's guaranteed expenses and the remaining losses afterwards. Therefore, as the influence of Confucianism increases, agency costs will decrease. Bi Wei from the perspective of the combination of formal system and informal system, using the environmental information disclosed in the 2007-2012 annual report and independent report of China's heavy pollution industry to conduct empirical research, respectively discussing the traditional culture and formality of the informal system. The role 
of the institutional environmental system in the disclosure of corporate environmental information. The study found that environmental systems and traditional cultures are positively correlated with the level of information environment disclosure, while traditional culture and environmental systems have complementary effects. Cheng Bo embeds Confucianism in Chinese traditional culture into the framework of internal control quality analysis, puts forward the hypothesis of self-discipline mechanism, and conducts theoretical discussion and empirical test on the relationship between Confucian culture and internal control. The research results show that Confucian culture can improve the information environment and strengthen contract performance to a certain extent, which contributes to the improvement of internal control quality and plays a more prominent role in companies with high information asymmetry.

\section{Literature Review and Inspiration}

In summary, the existing literature has studied the impact of culture on economic development, corporate and individual behavior, and accounting and auditing. The foreign literature research culture is mainly concentrated on religious culture and transnational culture, while domestic cultural studies are relatively less, mainly in traditional culture and Confucian culture, among which Bi Qian studies the influence of traditional culture on corporate environmental information disclosure, Gu Zhihui, and Cheng Bo study Confucian culture on corporate agents. The impact of cost and internal control, at the institutional level, especially the informal institutional factors, has little impact on audit fees and audit quality. Future research can classify traditional Chinese culture into religious culture and human culture to explore audit fees. And the impact of audit quality can better reflect the impact of traditional culture on auditing. This study only reviews the relevant literature on the impact of culture on auditing, and does not use quantitative methods to verify the extent and impact of the impact. This is a good research direction.

\section{Conflicts of Interest}

The author declares no conflicts of interest regarding the publication of this paper.

\section{References}

[1] Simunic, D. (1980) The Pricing of Audit Services-Theory and Evidence. Journal of Accounting Research, 18, 161-190. https://doi.org/10.2307/2490397

[2] Chen, S., Sun, S.J. and Wu, D. (2010) Client Importance, Institutional Improvements, and Audit Quality in China: An Office and Individual Auditor Level Analysis. Accounting Review, 85, 127-158. https://doi.org/10.2308/accr.2010.85.1.127

[3] Guiso, L., Sapienza, P. and Zingales, L. (2009) Cultural Biases in Economic Exchange? Quarterly Journal of Economics, 124, 1095-1131.

https://doi.org/10.1162/qjec.2009.124.3.1095 
[4] Paxton, P. (1999) Is Social Capital Declining in the United States? A Multiple Indicator Assessment. American Journal of Sociology, 105, 88-127. https://doi.org/10.1086/210268

[5] Hilary, G. and Hui, K.W. (2010) Does Religion Matter in Corporate Decision Making in America? Journal of Financial Economics, 93, 455-473. https://doi.org/10.1016/j.jfineco.2008.10.001

[6] Griffin, P.A. and Sun, E. (2013) Voluntary Corporate Social Responsibility Disclosure and Religion. SSRN Electronic Journal.

[7] Dimaggio, P. (1997) Culture and Cognition. Metaphilosophy, 23, 263-287.

[8] Simonen, J. and Mccann, P. (2008) Firm Innovation: The Influence of R\&D Cooperation and the Geography of Human Capital Inputs. Journal of Urban Economics, 64, 146-154. https://doi.org/10.1016/j.jue.2007.10.002

[9] Dyreng, S.D., Mayew, W.J. and Williams, C.D. (2012) Religious Social Norms and Corporate Financial Reporting. Journal of Business Finance \& Accounting, 39, 845-875. https://doi.org/10.1111/j.1468-5957.2012.02295.x

[10] Schultz, J.J. and Lopez, T.J. (2001) The Impact of National Influence on Accounting Estimates: Implications for International Accounting Standard-Setters. The International Journal of Accounting, 36, 271-290. https://doi.org/10.1016/S0020-7063(01)00103-0

[11] Tsakumis, G.T., Dean, G.W. and Jones, S. (2014) The Influence of Culture on Accountants' Application of Financial Reporting Rules. Abacus, 43, 27-48. https://doi.org/10.1111/j.1467-6281.2007.00216.x

[12] Clements, C.E., Neill, J.D. and Stovall, O.S. (2009) The Impact of Cultural Differences on the Convergence of International Accounting Codes of Ethics. Journal of Business Ethics, 90, 383-391. https://doi.org/10.1007/s10551-010-0417-1 